\title{
ANALYSIS OF THE PROMOTION OF THE HISTORIC CENTER OF MANAUS IN THE CITY'S PRINTED TOURIST GUIDES
}

\author{
Sibelle da Silva Oliveiraa; \\ Márcia Raquel Cavalcante Guimarãesb; \\ Ellen Lima Pratac; \\ Iara Farias da Silvad;
}

\begin{abstract}
This article investigates the tourist promotion of the Historic Center of Manaus through the city's printed tourist guides. This analysis was prompted by a lack of promotional materials on the oldest central area of the city, whether in printed and digital media. Yet this is the locality with the highest concentration of cultural tourist attractions in Manaus, and it recognized through patrimonial protection at federal, state and municipal levels. The study analyzes the city's tourist guides, and their relationship with the tourism promotion of its historic center. Nine tourist guides were used, from different years, to determine whether they met the needs presented. The consultation of the guides characterizes the research as documentary, since the material was not submitted to analytical treatment. It is also defined as bibliographic, due to the construction of the theoretical contribution. The results demonstrated that the tourist promotion of the Historic Center of Manaus is insufficient in the guides consulted. In order to promote the area in question, the development of a tourist guide to the city's oldest quarter is proposed, to be produced in both printed and digital formats, due to its historical importance and significant attractiveness in forming the image of Manaus as a tourist destination, qualified experience of visitors as well as the influence of the experience on the choice of tourist.
\end{abstract}

\section{PaLAVRAS-CHAVE}

Promotion

Historical Center of Manaus

Tourist Guide 


\section{INTRODUCTION}

Historical areas of cities are an important part of the tourist offer. Often attractive, these localities are known by various expressions, such as such as historical quarter, historical center, and old center, among others. They are places that consist mostly of built historical heritage that is related to the origin of the place and to the period of economic wealth that led to their construction. Beni (1998, p.278) describes these sites of historical relevance as "areas that, for historical and/or artistic reasons, represent important testimonies to national, regional or local culture."

Boullón (2002), Ignarra (2003) and Dias (2003) consider tourist attractions as raw material for tourism, because it is from these that a range of services integrated with trade and associated with tourism begin to exist. Therefore, cities that have historical characteristics present great potential for the development of cultural tourism, due to their set of attractions, giving rise to services and equipment that complete the tourist offer.

Therefore, it is important to develop the tourist promotion of these places, because working with strategies to promote historic centers increases the potential attractiveness of the place, attracting more visitors and investments. It is also important to be attentive to the sustainable planning of activities, ensuring economic, social and environmental development.

In order to foster tourism development and facilitate the movement and stay visitors, and seeking to publicize destinations and their respective offers, tourist guides provide even greater freedom in the choice of what attracting to see, acting as a form of communication. Zillinger (2004, p.03) states that "over time, guidebooks have influenced tourists both in the choice of destination and in the choice of attractions to be visited."

The travel experience becomes more personalized, establishing greater interaction between the place and those who visit it. The tourist guide acts as a source of consultation to plan the trip and the tourist's stay in the place, besides being a tool for tourist promotion. Murta \& Goodey (2002, p.23) emphasize that "leaflets, information boards, maps and illustra- ted guides, aimed at both local residents and visitors, are essential".

Given the above, this article discusses an analysis of the promotion of the Historic Center of Manaus in the city's tourist guides. This investigation was prompted by the observation that the central historical area does not have printed or digital material dedicated exclusively to its tourism promotion. Therefore, this work sought to verify, in the printed tourist guides of Manaus published in different years, if they met this need. As of the time of research, no more recent printed guide had been produced, whether of the historical center or of the city as a whole.

The Historic Center of Manaus is the locality that presents the largest amount of cultural attractions in the city, being under built historical heritage protection at federal, state and municipal levels. However, despite this, there are no promotional materials that focus exclusively on the place where the city's development first began. Due to this gap, the research problem can be summarized as follows: do the tourist guides of Manaus effectively promote its historic center?

To answer this question, this study analyzes the city's tourist guides and their relationship with the tourism promotion of its historic center. Nine printed tourist guides of Manaus were consulted, to see what information is conveyed about the center and whether they effectively promote this historic location. The analysis generated results that provide advances in studies and research in an area of tourism that is little explored.

It is important to point out that the capital of Amazonas is a historical city, with a wealth of possibilities for a more robust development of cultural tourism. Leal (2006) affirms that tourist destinations must invest in marketing and destination image, in order to develop and attract visitors.

This article is divided into four sections: a) theoretical background to the main theme of the study; b) methodological aspects of the research in terms of the form of survey and analysis of the data; c) results and discussions, which summarize the results of the content analysis of the printed tourist guides; and, finally, d) final considerations, which summarize the subject and bring scientific and marketing contributions about the theme addressed. 


\section{THEORETICAL BACKGROUND}

\section{The use of tourist guides as a marketing strategy for a destination}

Marketing is a strategy that adds value to the product, aiming to satisfy the needs and preferences of existing or potential customers, and for this, it is necessary to conduct market research and invest in advertising campaigns, among other actions, highlight the authors Fernandes, Ribeiro \& Lima (2019). Marketing is an indispensable component in any sector, especially the tourism sector, when it comes to the development of a tourist destination, say Moreira, Mesquita, Vianna \& Linhares (2018).

According to Gândara (2008), promoting the image of a location is an essential part of the marketing strategy for any tourist destination. This process is important because of the perception generated in the tourist about the most diverse destinations that they intend to visit, influencing their decision-making. "It is noted that a tourism location cannot be transported to the consumer, therefore the consumer must be attracted to the place", state Marujo \& Cravidão (2012, p.285).

In this sense, Sebastião (2016) reinforces that the use of marketing strategies makes it possible to strengthen the communication between the destination and the visitor, and when well used, it contributes to the dissemination, knowledge and raising awareness of information about the tourist service, affirming the importance of integrated marketing communication, as the most effective way to attract visitors to the place.

Among several possibilities, one way to advertise the destination or attractions is through advertising, Kotler \& Keller (2006) mention advertising as a means to build a lasting image of a tourist destination, as well as having a positive influence on its marketing, due to the communication it conveys. According to Ruschmann (2003, p. 70), "tourist advertising is considered an activity that influences and strives to persuade and make people accustomed to travel, proposing reasons to them that will create in them the desire to visit a certain place".

However, to reach a certain audience, marketing makes use of several media to promote a tourist destination, creating a link between the place and the tourist and showing all that can be found, explored and experienced there. Tojal (2014, p.371) emphasizes that "communication thus becomes the privileged vehicle for building the brand image of a tourism product in the mind of the potential consumer, and the printed media is one of the main channels for disseminating the image of a place".

Kotler \& Keller (2006) highlight that one of the most popular media used to publicize tourist destinations is local brochures, which are widely used companies and the public sector to disseminate information about the attractiveness of the place. Some of the materials that make up the promotional brochure include guides and tourist maps, pamphlets, posters, folders, postcards, and magazines, among others, whose primary function is to present the location by distributing promotional material, says Vaz (2001). Although the use of digital media for tourism promotion is on the increase, Tojal (2014, p.371) reinforces that "the role of small scattered communication objects, commonly known as leaflets or pamphlets, continues to be relevant in building the image of places that want to make themselves known to tourists". Given this relevance, the printed media has its value according to the objective to be achieved. This does not rule out the importance of digital media, but it is understood that there is room for both types of media in integrated tourism promotion.

Tourist promotion materials may be in the form of tourist guides, pocket guides or travel guides, all of which are important forms of communication for a tourist destination. These can be produced in printed or digital formats, and are widely used by tourists to obtain information about a particular destination, especially about the tourist offer of the locality. These materials also provide opportunities to promote the destination based on previous knowledge about what to see and do in the place.

Whatever marketing means are chosen to promote the destination, it should be mentioned that it is not only limited to advertising and sales but goes beyond that, focusing on ensuring customer satisfaction and creating a smooth, natural sales process that requires minimal effort, as stated by Kotler \& Keller 
(2006).

Thus, the tourist guide is also understood as a strategy to promote the destination, because it highlights the potential of the location and also acts as a tool for communication with the visitor, in which the sender of the message are the official tourism agencies or the private initiative. It is also seen as "a proposal to travel outside the place of habitual residence, structured through resources, to which tourist services are incorporated: transportation, accommodation, travel guides, food services, etc." according to Embratur, in the Aquarela Plan (2003-2006).

Monsú (2013, p.34) emphasizes that tourist guides "disseminate the image of a place and its geographical, cultural and social aspects, as well as covering practical issues such as attractions, unique characteristics, services and establishments". The tourist experience becomes much more valuable and satisfying to the visitor who is armed with the necessary information and knowledge to plan his stay in the city.

Tourist guides work with the reader's imagination, enabling the reader to make a trip even before they travel to the destination, with information about the historical context and pictures of the attractions, highlighting the services available in the region, among other information, that enables the potential tourist to plan the trip so dreamed about. And even during the trip, the guide is still a great ally of the tourist, who can consult it as needed. This corroborates with the statement of Torres (2006, p.06) that "after all, the representations of the cities presented by the media end up fixing scenes, portraying, illustrating, reproducing and synthesizing the reality of a city".

For Brown \& Chalmers (2003), city guides and maps are two types of publication that are essential to tourists while visiting certain tourist destination. Communication and information are the main purposes of a tourist guide, besides promoting the destination and locality, both for potential visitors to the region, and for those already in the region.

Given the above, it is clear that there is a new type of traveler, the independent tourist, the one who "when seeking personalized services on their own, book hotels and airline tickets without the direct help of agencies, the new consumer adds more and more characteristics of an independent traveler" says Brilhante (2013, p.36).

Also according to Brown \& Chalmers (2003), the importance of travel guides has an effect before, during and after a trip. Before the trip, they whet the appetite for a destination i.e. it gives information about what is available. During the trip, it makes use of the same information, giving the tourist options and flexibility, and information that may be useful in the event of unforeseen occurrences. After the trip, the guide may be used by the tourist when recounting their experiences to others; it may be passed on to others, becoming a tool in word-of-mouth marketing and creating an interest in others for the same destination. Brilhante (2013, p.44) adds that "besides word of mouth and travel guides, a third actor appears; the Internet, which ends up increasing these first two sources".

Kosaka (2009, p.10) points out that "the changes in society, the search for increasingly individualized products and the ease of traveling more independently in the era of globalization are driving the growth of this segment (independent travelers)," since access to online information is available to everyone. However, high street travel agencies continue to operate, and many consumers prefer to use their services when planning trips. But with new technology, everything can be accessed with just one click it is possible to access everything, the independent tourist appears, states Brilhante (2013).

Although the Internet facilitates the dissemination of information, the sources are not always secure and reliable, which is an advantage of printed tour guides, the content of which can also be made available digitally. Therefore, both options, printed and digital, exert a significant influence on decision making: What to do? When to do it? And where to do it?

Nova (2008) points out that the printed guide works as a bridge that connects the visitor to the locality. It is important to elaborate tourist guides for localities that still do not have them, as these are essential for independent tourists, who tend to purchase a guide as soon as they arrive at their destination. According to the authors Hyde \& Lawson (2003, p.15) the characteristics of independent travelers are:

- The main motivation of the independent traveler is the pleasure of living unplanned experiences in detail; 
- They make detailed plans on the choice of attractions and activities within a period of around 24 hours;

- They seek more detailed information on arrival at the destination;

- The most influential sources in the preparation of pre -planned travel elements are printed sources, such as travel guides and brochures.

Brilhante (2013, p.46) emphasizes that "as information is needed for the tourism market, the way it is offered, as well as its quality, can also make a difference when trying to cover a certain segment of travelers". The independent tourist differs from the mass tourist in that he or she is searching for authentic and unique experiences, always interacting with the local residents and the environment in which they are inserted.

Therefore, the tourist guide is an informative material, it contains information about the tourist offer: attractions, services and tourist equipment. The purpose of this material is to support the activities for tourism purposes, and it is therefore essential when it comes to promoting local tourism.

\section{Historic centers in the context of the tourism pro- motion}

PHistorical centers are the oldest sites of a city, a place of memories that represent the dynamics that occurred during the various phases of economic expansion of the city. In the oldest areas of the urban centers, tourists can visit monuments and other aspects of the historical and cultural heritage. It is the space that gives life to the city, maintaining its authenticity, as its cultural, artistic and historical value strengthens the city's tourist potential through its attractions and unique characteristics.

Jorge Hardoy (1986) emphasizes that historic centers are places where people live and work, because they are spaces with productive activities and services, and other districts of the city are interconnected to the center, both historically and in daily life. Local culture is also present in the central areas, as well as the built heritage that is concentrated, in particular, in those urban spaces of the city that contain the heritage of the past, with considerable evidence of the local social and economic history.

Keeping cultural heritage intact is one of the major challenges of the tourism sector. This includes minimizing the negative impacts that can occur due to lack of adequate planning and development of tourism activities. "Tourism requires spatial rearrangements, adaptation of elements and landscape reconfigurations. The influx of tourists and the adaptation of cities to the new social uses imposed by this activity focus on urban planning itself," add Carvalho, Coelho \& Bonfim (2011, p. 210-211).

Enhancing the appreciation of the central areas is the greatest challenges to be faced, but based on actions aimed at ensuring protection of the historical and cultural heritage, contributions are being made towards preserving the cultural heritage for the enjoyment of future generations. According to Zanirato \& Ribeiro (2006), the cultural heritage is now recognized at international, national, state and municipal levels, ensuring the preservation of tangible and intangible, cultural or natural material assets.

Thus, cultural valorization occurs from the moment that there is a greater appropriation of local history. Highlighting the historical trajectory of the locality can help prevent cultural losses, favoring the view that the history that constitutes the place is unique, being culturally significant and able to generate a bridge between the past and the present.

Through public or private initiatives aimed at enhancing the historic centers for tourism, the cultural heritage becomes an asset of great tourist potential and invaluable historical value. In the context of the tourism consumer market, the central areas become spaces for interaction between local residents and visitors. Tourism activities redefine how the heritage is used. For example, in the Historic Center of São Luís, in the State of Maranhão: "The cultural legacy that was constituted over time gave the city the greatest title of cultural heritage of humanity, a fact that triggered a process of economic and sociocultural promotion, the effects of which can still be seen today " emphasize Carvalho \& Simões (2012, p.205-206).

It is therefore important to recognize the cultural heritage in the context of promotion and economic development, because working with promotional strategies 
in historic centers increases the attractiveness of the place. According to Cifelli \& Peixoto (2012), in the case of Pelourinho, the Historic Center of the city of Salvador in the State of Bahia, through the Integrated Action Plan of the Historic Center of Salvador, executed by the Institute of Patrimônio Artístico Cultural da Bahia (Cultural Artistic Heritage of Bahia - IPAC) and the Companhia de Desenvolvimento Metropolitano de Salvador (Metropolitan Development Company of Salvador), the various actions including restoration of historical buildings, and creation and expansion of the tourist offer, particularly the cultural attractions. There were also government incentives for enterprises focused on tourist services and commerce, and the promotion of cultural events.

Clearly, the preservation and structuring of the tourist destination, where possible, should take place before the promotion, because it is necessary to be prepared to receive the desired demand. Based on this premise, strategic planning is an important tool for decisionmaking. On the other hand, there are historical centers that still yearn for change and for public representatives that have a vision of the tourist market, so that they effectively change the local reality through the preservation of historical areas. But there is nothing to stop private initiatives from working on the promotion even before this change takes place. Thus, there are countless possibilities for adding value to the historical location.

In the case of historical centers, it is recommended that these sites be marketed, seeking to "design a place in a way that meets the needs of their target markets" as Kotler et al., state (2007, p.148). In other words, local development occurs when an image of destination is created that attracts a specific demand. Scherer, Froemming, Fernandes \& Botelho (2017, p.126) consider that in the marketing of places, the process is continuous and involves citizens, both in the public and private spheres, because the objective is the same for both spheres: to develop the local community.

The marketing of places, according to Kotler et al., (2007), associated with the marketing mix of Petrocchi (2004), characterizes the Historic Center of Manaus and its tourist offer, the object of research of this work, as the product; while the tourist guide promotes the pro- duct in the context of marketing strategies. It is of great importance in studies on tourism to establish parameters when formulating the image of the tourist destination, because this item influences the decisionmaking process of the purchase, in the mind of potential tourists. Tourist destinations need to invest in marketing and, consequently, in the image that this destination has, in order to develop the region and attract visitors, emphasizes Leal (2006).

Thus, the importance of analyzing the information, images and messages transmitted by the promotional instrument tourist guide is justified, due to the understanding that the destination image directly influences the process of decision-making in tourists' purchasing, and their expectations and satisfaction.

\section{METHODOLOGICAL ASPECTS}

Based on Dencker (1998), the research objectives of this study were exploratory and qualitative in nature, since it investigates, in depth, the theme of tourist guides as important tools for tourism promotion; it is also descriptive, as it reports the reasons for the current situation, explaining the characteristics of the collected data. The research procedures were documentary and bibliographic, as we consulted books, journals, journals, scientific articles, monographs, dissertations and theses, to obtain theoretical input on subjects related to the research. The consultation of city tourist guides is characterized as documentary research due to the fact that it does not undergo analytical treatment, these being documents that record information relevant to the study.

For the data collection, this study uses nine tourist guides of Manaus, published in 2005, 2013, 2014 and 2016, in order to investigate the tourist promotion of its historic center. In the results section, we include images on the cover of each printed tour guide analyzed. For better visualization of the data obtained, a summary table is presented. It is important to emphasize that as at the time of the survey, no more recent guides had been published. 


\section{RESULTS AND DISCUSSIONS}

\section{Historical Context of the Historical Center of Ma- naus}

The city of Manaus, capital of the State of Amazonas, is located in the northern region of Brazil, and is part of the largest tropical rainforest and watershed of the world. The city first began as an indigenous village around the fortress known as the Fortaleza de São José da Barra. On October 24, 1669 it was founded and elevated to the category of city, and 2019 marks a history of 350 years. The Historic Center of Manaus is where it all began; the city's landmark.

Mesquita (2019) points out that the most significant changes occurred in the city between the years 1890 to 1920, phase of economic prosperity in which Manaus was transformed. This was a period known as the rubber cycle, gum economy or belle époque Manauara, which originated in the raw material of milky substance; latex, extracted from rubber trees (hevea brasiliensis), a species native to the Amazon Forest and widely used to produce rubber that was exported overseas.

The rubber boom attracted many workers to the region, all in search of wealth. But the reality was characterized by lots of hard work for little financial return, poor housing and food, and basically, a situation where the workers had to spend all they earned just to survive. Only the wealthy landowners and merchants benefited from the latex production, and the state was also enriched from their taxes, says Mesquita (2019).

The public coffers prospered and the Eduardo Gonçalves Ribeiro Government (1892-1896) began to invest in the city. Manaus was slowly becoming the Paris of the Tropics, acquiring a cosmopolitan culture and losing its native characteristics. The city, located on the north bank of the Negro river, was built in European style, as seen in the public parks of the Historic Center, describes Guimarães (2016).

This locality is protected at federal, state and municipal levels. State and federal listed building status were granted individually, but in 2010, the Instituto do Patrimônio Histórico e Artístico Nacional - IPHAN/AM (Institute of National Historical and Artistic Heritage of the State of Amazonas) expanded the listing building status to include the surroundings of properties that were already listed, inserting the Historic Center of Manaus in the list of historic Brazilian cities under national protection. For protection at municipal level, the Organic Law of the Municipality of Manaus - LOMAN (1990) cites, in Article 332, that will act in the municipality for the "identification, protection, conservation, restoration, valuation and recovery of the historical-cultural, architectural and landscape heritage of the city, including works of art, objects, documents and property". The same law also delimits and denominates the oldest urban area as a Historic Site, and an even larger area is defined as an Old Center or Historic Center, as shown in figure 1 . This area is predominated by the built historical heritage, the jewel in the crown being the Belle Époque Manauara: the Teatro Amazonas (Amazonas Opera House).

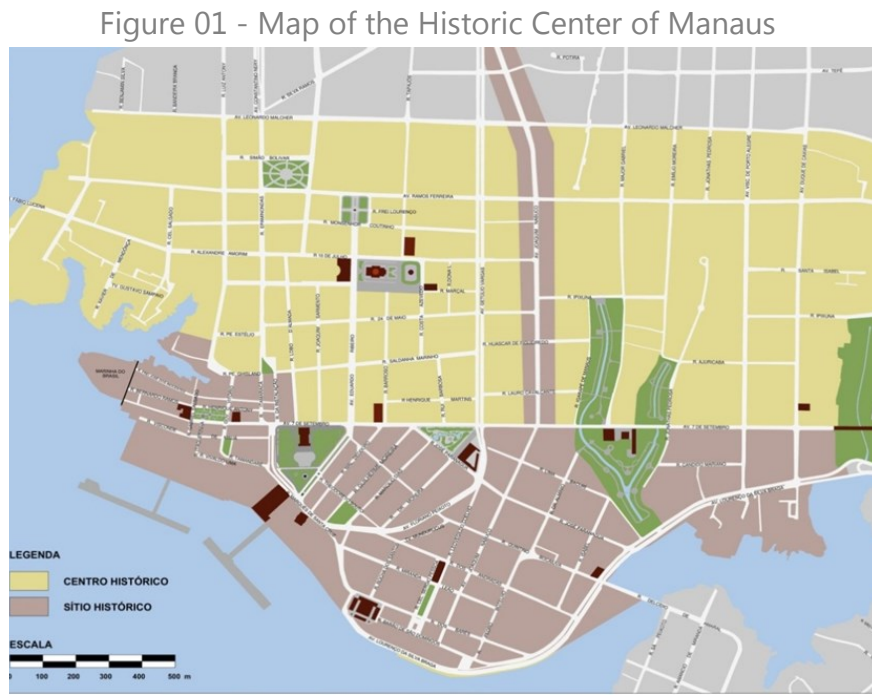

Source: Map provided by Manauscult, in 2017.

Thus, the listing granted by the Organic Law of the Municipality of Manaus - LOMAN (1990) denominates the central area as Old Center. The Instituto do Patrimônio Histórico e Artístico Nacional - IPHAN/AM (2010) (Institute of National Historical and Artistic Heritage), meanwhile, calls this area the Historic Center of Manaus. Whatever name is given, the protection of the central reaffirms its historical importance, with museums, theaters, cultural centers, residences, shops, squares and parks that together, comprise the built historical heritage. 


\section{Analysis of the promotion of the Historical Center in the printed tourist guides of Manaus}

The Historic Center of Manaus is the locality that presents the largest number of cultural attractions in the city, yet there is no printed or digital material dedicated exclusively to its promotion as a tourist product. This study therefore analyzes the tourist guides of Manaus that were available for consultation, published by public tourism agencies and private sector organizations, seeking to determine their relationship with the historic center, and investigating the type of information disseminated in them. Nine printed tourist guides to Manaus were consulted; they are presented below.

Figure 02 - Guia turístico de Manaus 2005

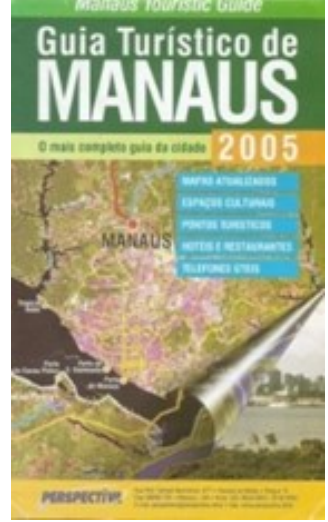

Source: Perspectiva (2005)

Figure 03 - Tourist Guide to Manaus

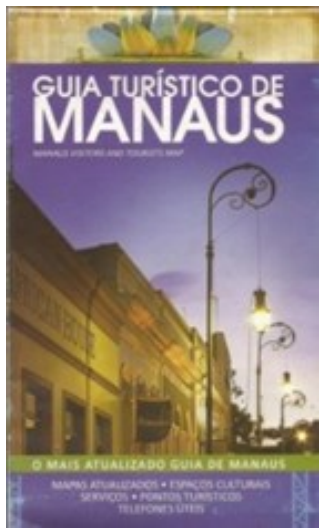

Source: Amazonastur (2005)
The Guia turístico de Manaus 2005 (Tourist Guide to Manaus 2005) (figure 2) was edited and published by the company Perspectiva. It gives a short description of the city, the country's currency, useful telephone numbers for emergencies, and information about services such as car rental, taxis, hotels and jungle lodges, and consulates. There are also three maps of the city; one showing the area surrounding Manaus, and two showing the administrative zones of the city of Manaus. One of these maps indicates the tourist offer: restaurants, hotels, tourist attractions, cultural spaces, museums, handicraft outlets, internet services, ecological spaces, sports facilities, shopping centers, port, bus terminals and health services, all of which are listed with telephone numbers. However, none of the maps specifically shows the Historic Center of Manaus. A large number of attractions are listed that are located in the historical center, but only directions on how to get there are given, without any information about their opening hours, for example, which is important for the visitor. There is no attempt to specifically promote the historical center.

The Guia turístico de Manaus (Tourist Guide to Manaus) (figure 3 ) follows the same description of the previous guide, the only difference being that it does not have a map of the administrative zones of the city. Some images are shown of the city's attractions, some of which are in the historical center. However, even though the majority of the attractions presented in the guide are in the historical center, this area is not specifically promoted.

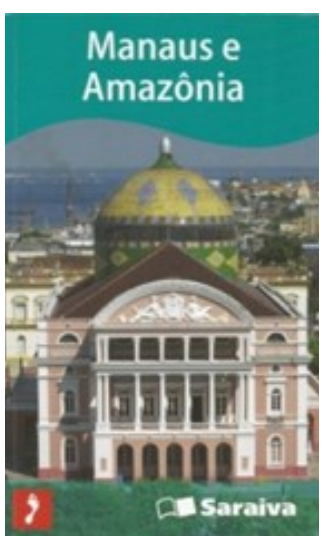

Source: Saraiva(2013) 
Figure 05 - Mais Manaus

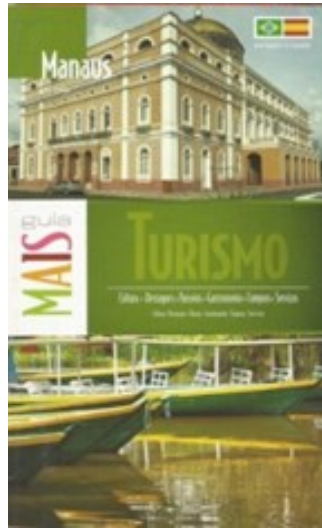

Source: Carvajal (2013)
Figure 06 - Manaus Metrópole de Amazonia

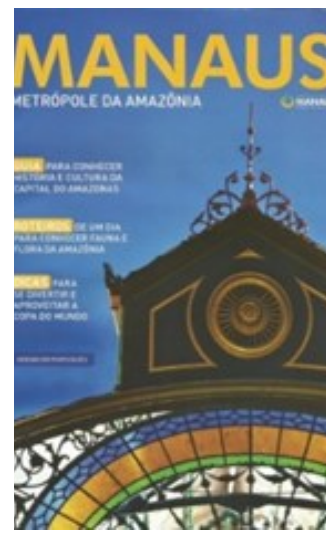

Source: Manauscult (2014)

Figure 07 - GuiaTur Manaus

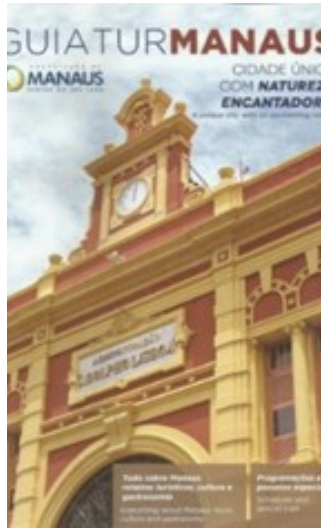

Source: Manauscult (2014)

to meet the needs of football fans arriving in Manaus to watch the games. The guide recommends cultural and nature tours and what to do in the outskirts of the city, and indicates some accommodation services, restaurants, entertainment and shopping centers, whether for those staying for a weekend, or those spending the whole week in the city. The guide contextualizes the history of the main cultural attractions present in the Historic Center of Manaus that receive visitors. It recommends where to start a tour, and shows a map of the historical center, illustrated with small representations of the attractions, and their addresses, telephone numbers and opening hours. There is little promotion of the historical center per se.

The GuiaTur Manaus guide (figure 7) was prepared in the same way as the previous guide, presents a universal model to facilitate communication between the city 
and the tourist. It is bilingual, written in Portuguese and English. It gives a brief history of the city, recommends what to do, where to buy, where to eat, where to stay, and other useful information. It gives a recommended 48-hour itinerary that will give the visitor to Manaus a good regional experience. Like the other guides mentioned above, it mentions some of the attractions of the historical center individually, but without linking them to any of the other attractions within the historical center, i.e. there is no promotion of the area where most of the attractions are concentrations.

Figure 08 - Manaus na Palma da Mão

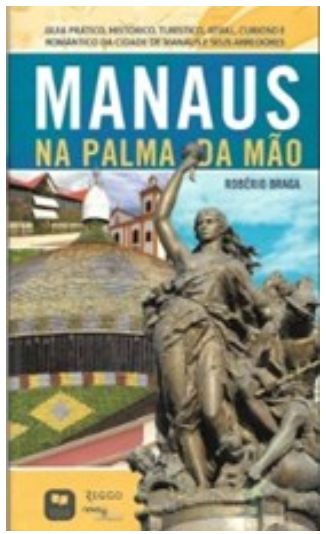

Source: Braga (2014)

The guide Manaus na Palma da Mão (Manaus in the Palm of Your Hand) (figure 8) is described as a practical, historical, tourist, up-to-date, inquisitive and romantic guide to the city of Manaus and its surroundings. It was published in 2014 by Robério Braga, author of several other works on the history of Manaus and the Amazon, and professor, lawyer and chronicler in the Amazonian press. He was also Secretary of Culture of the State. This guide highlights the history, customs and traditions of the city in a way that is simple and practical to use, with captions and symbols, maps and photographs. It divides the city by regions, including a section on the Historic Center of Manaus, contextualizing the area and its listed heritage status, between Old Center and Historic Site, and showing a map of the area. The cultural attractions are all described in detail, including the monuments, historical buildings that served as residences, theaters, palaces and that are now cultural centers and museums, and others that still retain their original functions. It also describes the squares and parks. Details are given such as addresses, telephone numbers, opening hours and entry fees, whether a tour guide is available, accessibility, and other information. This guide actively promotes the Historic Center of Manaus.

Figure 09 - Manaus Guia do Bolso

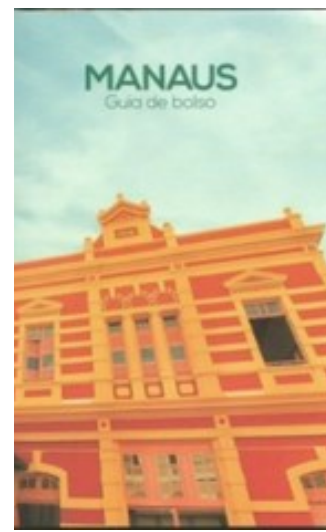

Source: Manauscult (2016)

Figure 10 - Manaus no Bolso

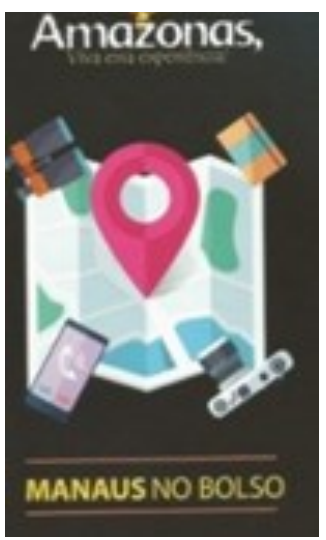

Source: Manauscult (2016)

The guides Manaus Guia do Bolso (Manaus Pocket Guide) (figure 9) and Manaus no Bolso (Manaus in Your Pocket) (figure 10) have similar content to each other because they were both published the City of Manaus, through its Municipal Foundation of Culture, Tourism and Events - Manauscult (2016). However, the Manaus No Bolso (figure 10) was published by the State Tourism Company of Amazonas - Amazonastur of the State Government, but cites Manauscult as a source. Therefore, both guides present the same content.

Being pocket guides, they contain less information about the attractions, focusing only the most popular 
ones. On the back, there is a map the highlights only the locations of the attractions mentioned in the guide, but it is merely illustrative and not drawn to scale, giving the impression that the attractions are closer to each other than they really are, and that the visitor could easily walk between them, which is not actually the case. There is no promotion of the historic center. In order to give a better understanding of the results obtained in the above analysis, the table below shows the most relevant notes on the nine printed tourist guides to Manaus:

Table 1: Summary table of the printed tour guides analyzed

\begin{tabular}{|c|c|c|}
\hline Year & $\begin{array}{l}\text { Printed Tourist Guides From } \\
\text { Manaus }\end{array}$ & Relation to the Promotion of Historic Center \\
\hline 2005 & $\begin{array}{l}\text { Guia turístico de Manaus } 2005 \\
\text { (figure 2) }\end{array}$ & $\begin{array}{l}\text { It lists the attractions, but does not visit all of them, and does } \\
\text { give information such as opening hours, There is no specific } \\
\text { promotion of the historic center. }\end{array}$ \\
\hline 2005 & $\begin{array}{l}\text { Guia turístico de Manaus } \\
\text { (figure 3) }\end{array}$ & $\begin{array}{l}\text { It lists the attractions, but does not visit all of them, and does } \\
\text { give information such as opening hours, There is no specific } \\
\text { promotion of the historic center. }\end{array}$ \\
\hline 2013 & $\begin{array}{l}\text { Manaus e Amazônia } \\
\text { (figure 4) }\end{array}$ & $\begin{array}{l}\text { It gives a brief historical contextualization of the Historic Cen- } \\
\text { ter of Manaus and mentions some of its most emblematic at- } \\
\text { tractions of the Belle Époque Manauara phase, but the attrac- } \\
\text { tions go beyond those mentioned. However, it does give a } \\
\text { brief overview of the Historic Center of Manaus. }\end{array}$ \\
\hline 2013 & $\begin{array}{l}\text { Mais Manaus } \\
\text { (figure 5) }\end{array}$ & $\begin{array}{l}\text { It mentions very few attractions of the historic center and is } \\
\text { incorrect on about the addresses of some. There is no promo- } \\
\text { tion of the Historic Center. }\end{array}$ \\
\hline 2014 & $\begin{array}{l}\text { Manaus Metrópole de Amazônia } \\
\text { (figure 6) }\end{array}$ & $\begin{array}{l}\text { It contextualizes the history of the main cultural attractions } \\
\text { that receive visitors, recommends where to start a tour, and } \\
\text { has a map of the center illustrated with small representations } \\
\text { of the attractions. There is little promotion of the Historic Cen- } \\
\text { ter. }\end{array}$ \\
\hline 2014 & $\begin{array}{l}\text { GuiaTur Manaus } \\
\text { (figure 7) }\end{array}$ & $\begin{array}{l}\text { It mentions some of the center's attractions, individually, with- } \\
\text { out considering linking them to the other attractions of the } \\
\text { historic Center. It mainly promotes the attractions, and not the } \\
\text { place where most of these are concentrated. }\end{array}$ \\
\hline 2014 & $\begin{array}{l}\text { Manaus na Palma da Mão } \\
\text { (figure 8) }\end{array}$ & $\begin{array}{l}\text { The Historic Center of Manaus is contextualized and its rise } \\
\text { and falls is explained. It also shows a map of the area. The cul- } \\
\text { tural attractions were all described in detail. This guide pro- } \\
\text { motes the Historic Center of Manaus. }\end{array}$ \\
\hline 2016 & $\begin{array}{l}\text { Manaus Guia do Bolso } \\
\text { (figure 9) }\end{array}$ & $\begin{array}{l}\text { It mentions some of the center's attractions, individually, with- } \\
\text { out linking them to the other attractions of the historic center. } \\
\text { There is no promotion of the historic center. }\end{array}$ \\
\hline 2016 & $\begin{array}{l}\text { Manaus no Bolso } \\
\text { (figure 10) }\end{array}$ & $\begin{array}{l}\text { It mentions some of the attractions of the historic center, indi- } \\
\text { vidually, without linking them to any of the other attractions of } \\
\text { the historic center, as a set of cultural attractions. The promo- } \\
\text { tion of the center is non-existent. }\end{array}$ \\
\hline
\end{tabular}


According to Table 1 above, the guides: 1 . Guia turístico de Manaus 2005, (figure 2); 2. Guia turístico de Manaus (figure 3); 3. Mais Manaus (figure 5); 4. GuiaTur Manaus (figure 7); 5. Manaus Guia de Bolso (figure 9) and 6. Manaus no Bolso (figure 10) present information about some attractions of the historic center, giving priority to the best-known ones, while failing to mention other attractions. They promote the attractions but not the place where these are concentrated. Therefore, the promotion of the Historic Center of Manaus is inadequate, because it is often not mentioned, and it not made clear that the city has a historic center.

The guides 1. Manaus e Amazônia (figure 4) and 2. Manaus Metrópole de Amazônia (figure 6) also present information about some attractions of the historic center, prioritizing the best known ones. They briefly contextualized about the Historic Center of Manaus and mention the attractions of the place. There is some promotion of the historic center, albeit very little.

The guide 1. Manaus na Palma da Mão (figure 8) is the only one that presents promotional content about the Historic Center of Manaus; it mentions the attractions in their entirety and highlights their locations within the historic center, i.e. it connects the attractions to the historical location to which they belongs. This guide also contextualizes historic center, explains the reasons for its rise and fall, and gives a map of the place. This is the only guide to fully promote the Historic Center of Manaus.

In conclusion, the nine printed tourist guides of the city of Manaus present attractions that are part of the historic center, which reinforces the importance of creating promotional material that focuses specifically for the oldest part of the city, and giving recommended routes for traveling between the attractions, and a map. Such an initiative would be of great value for promoting the historical center and its attractions, especially the lesser-known ones, which receive fewer visits due to the lack of information about them.

\section{The digital scenario}

The tourist promotion of the Historic Center of Manaus is insufficient both in printed form, as shown by the results of our analysis above, as in digital form. It was decided to restrict this study to printed guides due to ease of access to the material, since printed guides yielded more materials for analysis than electronic media. However, this section will briefly described the digital scenario of tourist guides of Manaus.

The printed tourist guides: 1. Manaus Metrópole de Amazônia (figure 6) and 2. GuiaTur Manaus (figure 7) give information about the GuiaTur Manaus mobile application and website, where tourists can find out more about the city and can acquire information in a practical way. However, an attempt to download this information was unsuccessful, as it was no longer available. Two other Apps were found: Guia Manaus 24h and Manaus Online, but both mobile application gave insufficient promotion of the historic center, mentioning only the attractions that it contains, and with some of the information in need of updating.

The website www.guiatur.manaus.am.gov.br has information about the cultural attractions of the city: libraries, cultural centers, historical buildings, churches, markets, monuments, museums, bridges, squares and parks, and theaters. Again, the attractions are mentioned, but they are not connected to the historical center. Also, the opening hours need to be updated. There is also the website guiamanaus24h.blogspot.com which gives information about museums, theater and tourism services, but it does not promote the Historical Center of Manaus.

No other digital guides were found, from reliable sources, about Manaus or its historicakl center. Therefore, like the printed guides, the digital scenario in general was shown to be insufficient as to the promotion of the Historic Center of Manaus.

\section{Applicability of scientific knowledge to the tourism market}

The city of Manaus needs to revive and promote its history so that residents and visitors can know and value the richness of its cultural heritage. For this purpose, it is proposed that a new tourist guide be created for the Historic Center of Manaus, since there is currently no published guide in existence, and it would be of great importance as promotional material for the area in question. According to Ignarra (2003), a tourist guide 
should contain the following information: 1. natural attractions; 2. cultural attractions; 3. calendar of events; 4. means of accommodation; 5. restaurants; 6 . car rental companies; 7. entertainment structures; 8. banks and foreign exchange facilities; 9. airports, railway and bus stations and waterway transport stations; 10 . embassies and consulates; 11 . medical services; 12 . authorized care mechanic workshops; 13 . places where handicrafts and typical products are sold; and 14. shopping.

Therefore, in order to produce a tourist guide, tourist planning must first be carried out, to make an inventory of the place. According to the Ministry of Tourism (2011, p.20), an "inventorying means registering, relating, counting and knowing what is available and generating information, to think about how to achieve a certain goal". Using this method makes it easier to construct the tourist guide.

Another possibility is to work with techniques of heritage interpretation, which aims, among other aspects, to act as a means of transmission of information on heritage, in addition to enriching the tourist's experience, facilitating access to the facts and striking aspects of the history of a place. Pupo (2011, p. 21) states that "to speak of heritage is necessarily, to speak of research, inventory, interpretation of material and immaterial objects, historical centers, sets of monuments, buildings, their mobile belongings and works of art, traditions, music, parties and the landscape that contains them".

There are several interpretation techniques, and each heritage has its own particularities, therefore each one must be properly planned, also focusing on the visitor's perception of the heritage. Similarly, Murta \& Goodey (2002) discusses the means and techniques of interpretation, which are divided into three categories: live interpretation, texts and publications, and design-based interpretation. For the purposes of this study, the category texts and publications applies, which are graphic representations that characterize the interpretation by means of maps, guides, scripts, folders, postcards, signs, panels, signs and communications.

Thus, the possibilities of developing a tourist guide integrated with marketing tools and techniques of heritage interpretation adds value to the material, because the objective is to promote the heritage as a resource for the development of tourist activities, dedicated to adding value to the visitor's experience and enabling them to appreciate the place in a holistic way, rather than as individual sites or attractions. This is the most appropriate method for historical centers that have a great wealth of built historical heritage.

The merit of this research lies in its theoretical contribution of aligning the themes of tourism marketing and interpretation of heritage that together, amplify the knowledge about a place about which there have been few studies, research or promotion, and that can effectively awaken interest in the potential of the historic center of Manaus as a tourist attraction, making this location more interesting for those who arrive in the city, as well as for residents of the city who many not know about its history. This study also has practical and market applicability, due to the possibility of elaborating a specific Tourist Guide to the Historical Center of Manaus that can attract the interest of public tourism agencies and the tourism industry in general.

\section{FINAL CONSIDERATIONS}

In this research, the content referring to the central area of the capital of Amazonas was analyzed, and it was found that there is inadequate promotion of the Historic Center of Manaus, with its attractions being covered individually, without considering them as a complex of interconnected goods and services. Eight of the nine guides consulted highlight only some of the attractions, leading the reader to believe that the historical center is limited only to what is mentioned, whereas in fact, it has greater variety.

It was noted that some of the guides are incomplete, as they fail to take into account the richness of the built historical heritage. In some places, important information is missing that could encourage the tourist to stay longer, e.g. showing that the attractions go beyond the natural beauty. Minciotti (2011, p.331) points out that "there are localities with potential for rebirth due to the historical, cultural and political heritage that can sustain a high flow of visitors, if adequately led, and with vision". 
The Historic Center of Manaus is the locality that presents the largest amount of cultural attractions in the city, and receives protection at federal, state and municipal levels. Even so, there are no promotional materials exclusive to the area. As a suggestion, to fill this gap, the development of more complete promotional material of the city's built cultural diversity is recommended, such as printed guides as guides and tourist maps, and also digital guides, as these will encourage people to travel to the destination.

Thus, the possibilities of developing a tourist guide that is integrated with marketing tools and techniques of heritage interpretation adds value to the material, because the objective is to promote heritage as a resource for the development of tourist activities, dedicated to valuing the visitor's experience and appreciating the place visited in a holistic way. In accordance with this article, the use of guides for the promotion of tourism in the Historic Center of Manaus is of paramount importance, bearing in mind that it should cover the historic center as a whole and not just isolated parts of it, as this would remedy the lack of published material on this specific area of great historical wealth.

\section{REFERÊNCIAS}

Beni, M. C. (1998). Análise Estrutural do Turismo. São Paulo: Editora SENAC São Paulo.

Boullón, R. C. (2002). Planejamento do espaço turístico. Bauru, SP: EDUSC.

Brilhante, M. N. (2013). Estudo comparativo de aplicativos de guias turísticos para dispositivos móveis: Lonely Planet e mTrip. Monografia (Bacharelado em Lazer e Turismo) Escola de Artes, Ciências e Humanidades da Universidade de São Paulo. São Paulo. 103 f.

Brown, B., \& Chalmers, M. (2003). Tourism and mobile technology. In: 'ECSCW'03: Proceedings of the eighth conference on European Conference on Computer Supported Cooperative Work', 3, 2003. Kluwer Academic Publishers, Norwell, MA, USA, pp.335-354.

Carvalho, K. D. \& Simões, M. L. N. (2012). Análise do modelo de preservação do Centro Histórico de São Luís do Maranhão: Uso social e uso turístico. Revista Turismo Visão e Ação Eletrônica, 14(2), 196-213.

Carvalho, K. D., Coelho, S., \& Bonfim, N. R. (2011). Turismo cultural e interpretativo na cidade de Ilhéus-Bahia: uma proposta de revitalização para a Avenida Soares Lopes. Caderno
Virtual de Turismo, 11(2), 205-218.

Cifelli, G., \& Peixoto, P. (2012). Centros históricos e turismo patrimonial: o pelourinho como exemplo de uma relação. Revista da Faculdade de Letras da Universidade do Porto, vol. XXIV.

Dencker, A. F. M. (1998). Métodos e técnicas em turismo. São Paulo: Futura.

Dias, R. (2003). Planejamento do Turismo. Política e desenvolvimento do turismo no Brasil. São Paulo: Atlas.

Embratur. (2003). Plano Aquarela 2003-2006. Brasí-lia: Embratur.

Fernandes, F.; Ribeiro, R. B. \& Lima, L. (2019). A promoção turística de Cabo Verde no mercado português. Revista de Turismo y Patrimonio Cultural - Pasos, 17(3), 509-526.

Gândara, J. M. G. (2008). A imagem dos destinos turísticos urbanos. Revista Eletrônica de Turismo Cultural, $n^{\circ}$ especial.

Guimarães, M. R. C. \& Ramos, A. C. S. M. (2016). Chão e Vão: uma Amazônia Construída. Jundiaí: Paco Editorial.

Hardoy, J. (1986). A Cidade Latino-Americana: a vigência dos centros históricos. Revista do Património Histórico e Artístico Nacional, $n^{\circ} 21$.

Hyde, K. \& Lawson, R. (2003). The Nature of Independent Travel. Journal of Travel Research, 42(1).

Ignarra, L. R. (2003). Fundamentos do turismo. São Paulo: Pioneira Thomson Learning.

Iphan. (2010). Tombamento do centro histórico de Manaus. Dossiê. Departamento de Patrimônio Material e Fiscalização DEPAM/IPHAN.

Kosaka, V. K. L. (2009). Distribuição On-line de Informações e Serviços Turísticos para o segmento de viajantes independentes no Brasil - o caso da WHL. TRAVEL. (Monografia). Instituto de Geociências. Universidade Federal Minas Gerais.

Kotler, P. \& Keller, K. L. (2006). Administração de marketing. São Paulo: Prentice Hall.

Kotler, P.; Gertner, D.; Rein, I. \& Donald, H. (2007). Marketing de lugares. São Paulo: Pearson Prentice Hall.

Leal, R. (2006). Uma abordagem conceitual-reflexiva sobre a relação da comunicação com o turismo. Caderno Virtual de Turismo, 6(1)

Marujo, M. N.; Cravidão, F. (2012). Turismo e Lugares: uma visão geográfica. Revista de Turismo y Patrimonio Cultural Pasos, 10(3), 281-288.

Mesquita, O. M. (2019). Manaus: história e arquitetura (16691915). Manaus: Editora Valer.

Minciotti, S. A. \& Silva, E. C. (2011). Marketing de localidades: uma abordagem ampliada sobre o desenvolvimento da cidade ou região. Revista Turismo Visão e Ação Eletrônica, 13(3), 329-346. 
Ministério do Turismo. (2011). Inventário da Oferta Turística. Ana Clévia Guerreiro Lima (Coordenadora) - Brasília: Ministério do Turismo.

Monsú, S. Z. (2013). Guia turístico impresso para uma experiência autêntica em Porto Alegre. Trabalho de Conclusão de Curso. Curso de Design Visual da Faculdade de Arquitetura e Urbanismo da Universidade Federal do Rio Grande do Sul.

Moreira, P.; Mesquita, J.; Vianna, K. \& Linhares, M. (2018). O efeito das ações de promoção turística internacional na comercialização de destinos turísticos. Revista Gestão \& Regionalidade, 34(101).

Murta, S. M. \& Goodey, B. (2002). A Interpretação do patrimônio para visitantes: um quadro conceitual. In: Murta, S. M. \& Albano, C. (Org). Interpretar o patrimônio: um exercício do olhar. Belo Horizonte: Ed. UFMG / Território Brasilis, p. 13-46.

Nova, M. R. (2008). Guias Impressos da Cidade de São Paulo: a exposição do patrimônio cultural. V Seminário de Pesquisa em Turismo do MERCOSUL - Semintur. Turismo: Inovações da Pesquisa na América Latina. Universidade de Caxias do Sul - UCS, Caxias do Sul, RS, Brasil 27 e 28 de Junho.

Petrocchi, M. (2004). Marketing para destinos turísticos. São Paulo: Futura.

Pupo, G. H. (2011). La interpretación del patrimonio cultural para la gestión turística. Retos Turísticos, 10(1-2), 21-27.

Ruschmann, D. V. M. (2003). Marketing turístico: um enfoque promocional. Campinas: Papirus.

Scherer, L.; Froemming, L.; Fernandes, S. \& Botelho, L. L. R. (2017). Marketing de lugares para gerenciamento de cidades - percepções sobre Cerro Largo/RS. Revista Nacional de Gerenciamento de Cidades, 05(35), 123-139.

Sebastião, S. P. (2016). Comunicação Integrada de Marketing. In: Ribeiro, R. B. (coord.), Marketing: do conhecimento à decisão. Lisboa: Causa das Regras. p. 201 -221.

Tojal, M. D. (2014). A importância dos folhetos e brochuras na construção da imagem de um destino turístico. Estudo comparativo de três casos: Vila do Conde, Póvoa de Varzim e Esposende. Revista de Turismo y Patrimonio Cultural-Pasos, 12(2), 369-382.

Torres, M. L. (2006). O Rio dos viajantes: Representações da cidade nos guias de turismo. Intercom - Sociedade Brasileira de Estudos Interdisciplinares da Comunicação. XXIX Congresso Brasileiro de Ciências da Comunicação - UnB - 6 a 9 de setembro.

Vaz, G. N. (2001). Marketing turístico receptivo e emissivo. São Paulo: Pioneira Thomson Learning.

Zanirato, S. H. \& Ribeiro, W. C. (2006). Patrimônio cultural: a percepção da natureza como um bem não renovável. Revista Brasileira de História, 26(51), 251-262.

Zillinger, M. (2004). German tourists and their use of guidebooks in Sweden: The influence of guidebooks on the choice of tourist destinations and travel routes. Ostersund: ETOUR - European Tourism Research Institute. 
(C)2019 autores, Publicado por Univali Esse artigo é de livre acesso sob a licença 